\title{
Why Do Students Choose Vocational School? Lesson Learned From Indonesian Vocational Education
}

\section{Pijar Suciati}

Communication Studies, Vocational Education Program, Universitas Indonesia, Depok, West Java, Indonesia

\section{Abstract}

In a life process, decision-making is considered very crucial, including determining the kind of education that one should choose in his/her life. Decision-making should be based on the information that is considered important. This research attempts to analyze the decision-making factors (relative educational cost, referral group, marketing communication, image, motivation, attitude, availability of employment in industrial world) toward the decision for choosing vocational program as higher

Corresponding Author:

Pijar Suciati

suciati.pijar@ui.ac.id

Received: 8 June 2018

Accepted: 17 July 2018

Published: 8 August 2018

Publishing services provided by Knowledge E

(c) Pijar Suciati. This article is distributed under the terms of the Creative Commons

Attribution License, which permits unrestricted use and redistribution provided that the original author and source are credited.

Selection and Peer-review under the responsibility of the 2 nd ICVHE Conference Committee.

\section{S OPEN ACCESS} education. This study is expected to provide some valuable information as the input for all parties who are interested in developing the vocational higher education. The sample used was taken from 97 students of Vocational Education Program of Universitas Indonesia, Class of 2014-2016. The gathered data were analyzed with factor analysis (confirmatory factors) and model verification by using SPSS Path Analysis. Based on the analysis, it was found that the internal and external factors were proved to have effects on decision-making to study in vocational higher education program. The highest correlation is the image of the institution that strongly affected the students' motivation.

Keywords: vocational education, decision-making factors, educational institution image

\section{Introduction}

Vocational education, perhaps more than any other area of the curriculum, has had to struggle, both within the educational community and with society at large, for its 'place' in the public schools. In a broad sense, vocational education is as old as civilization itself. Its U.S. beginnings can be traced to apprenticeship training, one of six types of 'schooling' brought to this country from England. The earliest New England colleges and secondary schools were also 'voca- tional' in nature (if theology can be considered a vocation), for both were established - since return to England was out of 
the question for the renegade Puritans - to ensure a local source of minsters [1]. The definition of vocational education is an education prepares people to work in a trade, a craft, as a technician, or in professional vocations such as engineering, accountancy, nursing, medicine, architecture, or law. Craft vocations are usually based on manual or practical activities and are traditionally non-academic but related to a specific trade or occupation. Vocational education is sometimes referred to as career education or technical education [2].

Vocational education can take place at the secondary, post-secondary, further education, and higher education level; and usually interact with the apprenticeship system. At the post-secondary level, vocational education is often provided by highly specialized trade, technical schools, community colleges, colleges of further education, universities, institutes of technology/polytechnic institutes. In Indonesia, vocational education is still considered as second level education. The paradigm of people and industry should be changed according to the high demand of skillful workers.

In 2016, the President of Republic Indonesia, Joko Widodo through the Minister of Research, Technology and Higher Education (Menristekdikti), Mohamad Nasir, admitted that high school or university graduates often cannot meet the needs of today's industry so that not a few graduates are just unemployed. To overcome these problems, the government wants to implement revitalization of vocational-based higher education. The purpose of the revitalization is to increase the relevance of polytechnic education with the needs of the user industry graduation so that the number of unemployment will decrease as the improvement of education system today [3]. In addition, Supervisor Chairman of Vocational Higher Education Forum Indonesia (FPTVI) Hotma Prawoto Sulistya, said that vocational graduates are better prepared to face the threat of invasion of foreign workers than the bachelor when MEA (Free Trade ASEAN) started [4].

The keyword that must be faced by all nations in the world today and forward is competition. The globalization makes the competition even tighter. To be able to win the competition there is no other choice unless each country has qualified human resources. Reviewing the picture of Indonesia's competitiveness in the face of increasingly global competition, the World Economic Forum provides data that based on the Global Competitiveness Index, Indonesia is at position 37 (2015-2016) [5] and declining to position 41 in 2016-2017 [6].

From the following data, clearly provide information that more qualified human resources owned by a country will get even greater opportunities for the country to win the competition and maximize the benefits of globalization. Globalization prescribes 
source preparation by the quality human resources (qualified human resources) of course with the level of competition and science, technologically capable, especially in communication technology, and supported by basic morality excavated from strong cultural wisdom and religious values. In other words it can be said that the future of a nation depends on how well the quality of education and human resources of it [7].

TABLE 1

Tabel. 1.1. Global Competitiveness Index of ASEAN Countries (2015-2016 and 2016-2017)

\begin{tabular}{|c|c|c|}
\hline Countries & Ranking 2015-2016 & Ranking 2016-2017 \\
\hline Singapore & 2 & 2 \\
\hline Malaysia & 18 & 25 \\
\hline Thailand & 32 & 34 \\
\hline Indonesia & 37 & 41 \\
\hline Philipines & 47 & 67 \\
\hline Vietnam & 56 & 60 \\
\hline Cambodia & 90 & 89 \\
\hline Brunei Darussalam & - & 68 \\
\hline Myanmar & 131 & - \\
\hline
\end{tabular}

Source: The Global Competitiveness Report (2015-2016) and (2016-2017) by World Economic Forum

Vocational education is very important in a developing country, like Indonesia. it is important to note that good vocational training can play an important role in economic development and reducing poverty. Also, there is certainly sufficient need to change current structures and functions. The question that should be asked, however, is under what circumstances can vocational training make a positive contribution. The orientation toward economic development is certainly necessary in principle [8].

Cited from The Guardian, developing countries could minimize skills mismatches by placing greater emphasis on TVET (Technical and Vocational Education Training). Vocational education tends to result in a faster transition into the workplace, and countries that have it at the core of the curriculum - such as Germany, Switzerland, Austria and the Netherlands - have been successful in maintaining low youth unemployment rates [9].

Indonesia as developing country, has aware of the importance of vocational education. Many universities established their own vocational program. Universitas Indonesia (UI) as number one, leading university in Indonesia, In the 1990 s established D3 Program (vocational) which was managed by faculty in accordance with the available majors. At that time, the faculties that run Diploma 3 programs were Faculty of Medicine, Faculty of Mathematics and Natural Sciences, Faculty of Public Health, Faculty of Economics, Faculty of Cultural Sciences, and Faculty of Social and Political 
Sciences. In 2008, the administrative management of Diploma $3 \mathrm{UI}$ was conducted centrally under the name Program Pendidikan Vokasi Universitas Indonesia [10].

This is done with the aim that $\mathrm{UI}$ can be more efficient in running vision and mission along with all faculty in UI. This is in line with the high interest of the community to become graduates who are ready to be absorbed by the industry. The majors provided by the Program Pendidikan Vokasi UI include the areas of Administration Studies (Insurance and Actuary, Finance and Banking, Office and Secretary, and Taxation), field of Accounting Studies (Financial Accounting) Study of Health Sciences (Physiotherapy, Occupational Therapy, and Hospital Management), the field of Communication Studies (Broadcasting, Advertising, and Public Relations), and the field of Tourism Studies [11].

\subsection{Problem statement}

Nowadays, Indonesian society is getting familiar with the term of vocational higher education. Moreover, the existence of vocational higher education in Indonesia is legally very clear in Undang Undang Nomor 20 Tahun 2003 on National Education System, and Undang Undang Nomor 12 tahun 2012 on Higher Education (UU PT). The law states that the type of education in Indonesia consists of academic education, vocational education, and professional education. Furthermore, in article 16 dari UU No. 12 tahun 2012 it is affirmed that vocational higher education can be developed to the level of Master of Applied, even to the highest level that is Applied Doctorate.

Indeed the substance of the law mandates the principle of equality between types of education, namely academic education, vocational education, and professional education. That is, in the development of these three types of education should run without discrimination. But during this academic education tend to prioritize, while vocational education and professional education as if positioned like a stepchild. Discrimination policy of education development like this of course have an effect on to society perception in view of educational world. Thus, it is only natural that vocational education is unpopular and is considered 'second class' education among the public, because the only people in the world are only academic [12].

From the aforementioned statement, it can be said that there is competition, between vocational education and academic education, in terms of winning the hearts of the community and industry. Prospective students are influenced by various factors in deciding to choose the type of programs, majors and universities as their higher education. 
In a life process, decision-making is considered very crucial, including to determined which kind of education should someone choose in their life. Decision-making should be based on the information that is considered important. This research attempts to analyze the decision-making factors toward the decision for choosing vocational program as higher education. This study is expected to provide some valuable information as the input for all parties who are interested in developing the vocational higher education.

\section{Theoretical Frameworks}

\subsection{Factors affecting the decision-making}

Hawkins et al. (2004) state that there are two main factors influencing decisionmaking, that is, external factors consisting of culture, sub culture, demographics, social status, (Reference group), family (family) and marketing activities (marketing activities), and internal factors consist of perception, learning, memory, motives, personality, emotions and attitudes as key determinants of buying decisions [13].

In its development, according to Kotler (2004) also explained more broadly that there are four main determinants that influence the consumer purchase decision namely:

- Cultural factors consisting of: culture, subculture and social class,

- Social factors consisting of: reference group, family, role and status,

- Personal factors consisting of: age and stage of life cycle, occupation, economy and lifestyle personality and self-concept

- Psychological factors consisting of: motivation, perception, learning, beliefs and attitudes [14].

Based on some aforementioned opinions, it can be concluded that in general there are two main factors that influence a person in buying goods or services that external factors that cannot be controlled and internal factors coming from within the consumer itself. This is evidenced by the results of research conducted by Hossler et al. (1985), Chapman (1981), Freeman (1999), Cambera and La Nasa's (2000) using several consumer behavior models found that demographic factors, socio-economic background, gender, family career background and individual characteristics of students influencing college selection decisions [15]. 


\subsection{External effect}

1. Relative Educational Cost

Price or cost of education to be spent not only can be judged from the high side of low, expensive or not, but can also be seen from the other side that is on how ability, perceive and feel the cost incurred associated with the feasibility, ease and properness in accessing the college A certain height. Thus the results of the assessment is very dependent on the economic ability, conditions and patterns of assessment subjectively by associating for example with the possibility of the value or quality to be received, affordability tuition fees, the fairness of tuition fees and so forth. To arrive at the conclusion of the assessment of the cost of education, various things can also be a consideration such as the number and qualifications of lecturers who have, completeness infra structure, services provided, academic reputation, management of managers and so forth. These are related to the cost of education before assessing whether the cost of education is fair or not and so forth. Because this assessment is of course very relative to each person so that the cost of education is called relative education costs. Thus the cost of this relative education cannot be interpreted the same as the price used to buy certain products.

On the other hand Schiffman and Kanuk (2007) explain that how consumers perceive a certain price-high, low, reasonable, have a strong influence on buying intent and buying satisfaction. This shows that a consumer judges the fairness of a product or service price depends on how to judge it. On the other hand, consumers also often link prices to the quality of products or services received as suggested by Schiffman and Kanuk (2007) which say that consumers use price as an indicator of quality if they have little information to hold or if they are unsure of their ability Alone to make choices on the basis of other things [16]. But if other cues are available to the consumer such as a brand, or store image, then sometimes it is more influential than price in determining quality. Similarly, proposed by Mowen in Ndaru Kusuma Dewi (2009) that consumers tend to use the price as a quality indicator. Schiffman \& Kanuk (1994) and Hawkins, Best \& Coney (1995) also say that price is a signal of quality. This can happen if the consumer is difficult to make decisions about quality objectively or by using a brand name or store image (Mowen, 1993) [17]. A research conducted by Dodds in Ndaru Kusuma Dewi (2009) states that consumers will buy one branded products if the price is considered feasible by them [18]. 


\section{Referral Group}

The reference group is an individual or group of persons deemed to have significant relevance to a person in terms of evaluating, giving aspiration, or in behaving [19]. Reference groups may also be the form of a person or group that is the comparator or reference of a person in the formation of values, attitudes, or behavior both in general and in particular [20]. In the same sense Peter and Olson (2005) argue that the Reference Group involves one or more people who serve as the basis of comparison between reference points in shaping affective and cognitive responses and expressing one's behavior [21].

The magnitude of the influence of the referral group on purchasing decisions is evidenced through the research conducted by Bearden and Etzel in (Peter and Olson, 2000), it was found that the influence of reference groups on product and brand decisions varied at least in two dimensions, namely the first dimension related to the extent of a Product or brand is something that is needed or a luxurious object and the second dimension is the extent to which the object being met is interesting or known to others.

\section{Marketing Communication}

When deciding on a consumer purchase decision to conduct extensive information retrieval and then process the information as a matter of consideration before finally deciding on a purchase. This shows the important role of communication in supporting the buying decision process, as presented by Henry Assael (1998) as follows [22]:

"Since they provide information that influences consumer's purchase, communications are central to consumer's decision making". For that reason it is not enough for a company to simply develop a product well, offer it at an attractive price, and make it easy for its targeted customers. However, the company must also communicate with existing customers, potential customers, retailers, suppliers, and other interested parties.

There are several sources of information that can help make decisions, Henry Assael (1998) puts it this way:

"To make purchasing decision, consumers acquire and process information from advertising, from their experience, with product, from friends 
and neighbors, and from others sources". In making purchasing decisions, consumers can obtain information from advertising from an experience of a product, from friends and neighbors and from other sources of information [23].

Therefore, it is important for every company is not excluded universities to organize marketing communications in helping and directing consumers in order to meet the wants and needs by way of awaken all parties involved in marketing communications to do better by providing information in accordance with the needs and desires of consumers. Moreover marketing communication is also very important to enhance the brand image as proposed by Meenaghan and Shipley (1999) that the importance of marketing communication in improving brand image It is also put forward by Graeff (1996) which more specifically discusses the importance of promotion in building a brand [24].

\subsection{Internal effect}

1. Image

Consumers tend to form an image of brands, stores, and companies based on their inferences derived from marketing and environmental stimuli. Image is the total perception of an object, formed by processing information from various sources every time [25].

While the perception according to Schiffman and Kanuk (2004) is as a process where in the process individuals choose, organize and interpret the stimuli into something meaningful. Perception has a very important role in marketing. The image that is in the minds of consumers arise because the process of perception, how consumers assess a service quality is also highly determined by perception, success in positioning the product is also very dependent on perceptions in the minds of consumers.

The image basically consists of 3 (three) parts of corporate image, product image, and brand image. Corporate image has a big role in influencing consumer decision-making. When consumers do not have complete information about products and brands, they will use the company image as the basis for choosing products. People sometimes do not like the product 
The process of motivation occurs because of the needs, desires and expectations that are not met which causes tension (Jeffrey et al., 1996). Meanwhile, according to Schiffman and Kanuk, 2007), motivation can be described as a driving force within individuals that force them to act. The driving force is generated which arises as a result of unmet needs. In a different sentence Supranto (2007) suggests that motivation indicates a reason for a behavior. Motivation is an energetic force that drives behavior and provides goals and direction of behavior [26].

While the Motivation Theory by McClelland, stated that humans have three basic needs that can motivate an individual to behave, namely: (1) The need for power is how far the individual wants to control and influence others and other objects that exist in the environment. Individuals who have high-power motives have a strong impetus to direct and change others or events occurring in surrounding. (2) The need for affiliation is the individual's need to gain warmth and establish closer relationships with others. Individuals with high-affiliated motives will tend to be more expressive in expressing their emotions and feelings to others, likes to work with others, like friends and social situations. (3) Needs achievement (needs for achievement), namely the human desire to achieve the best achievement, reputation and career.

\section{Attitude}

Understanding attitude was originally proposed by Thurstone (1993) where he sees attitudes as one fairly simple concept of the amount of influence a person has over or against an object. A few years later Gordon Allport proposed a broader sense of attitudes: mental and nervousness in terms of readiness to respond, organized through experience and having a directional and or dynamic influence on behavior. The definition put forward the meaning that the attitude is to study the tendency to respond to an object whether favored or not consistently. While Schiffman and Kanuk (2007) suggests in a more or less the same sense that attitude is an expression of feelings that come from within the individual that reflects whether a person Happy or unhappy, likes or dislikes and agrees or disagrees with an object. Similarly, the opinion expressed by Engel, Black Ward and Miniard (1995), who says that attitude shows what consumers like and dislike [27].

Basically many factors that can shape a person's attitude, especially related to the attitude of purchasing a product or service. According to Prasetijo, Ihalauw (2004) said that the main sources that influence the formation of consumer attitudes are: (1) Experience. Direct experience by consumers in trying and evaluating the 
product can affect consumer attitudes toward the product (2) Personality [22]. Family by Kindra et al. (1994) is an important factor in the formation of personality and subsequent formation of one's attitude. In that family, one forms the basic values and beliefs. In addition to family, contact with friends and other people around them, especially people who are admired, also influential in the formation of personality and attitudes of a person. (3) Information from mass media. Mass media which is a communication medium that almost every time found consumers can form consumer attitudes.

These external and internal factors of decision-making process are the variables of this research. They can be analyzed by using this kind of analytical model:

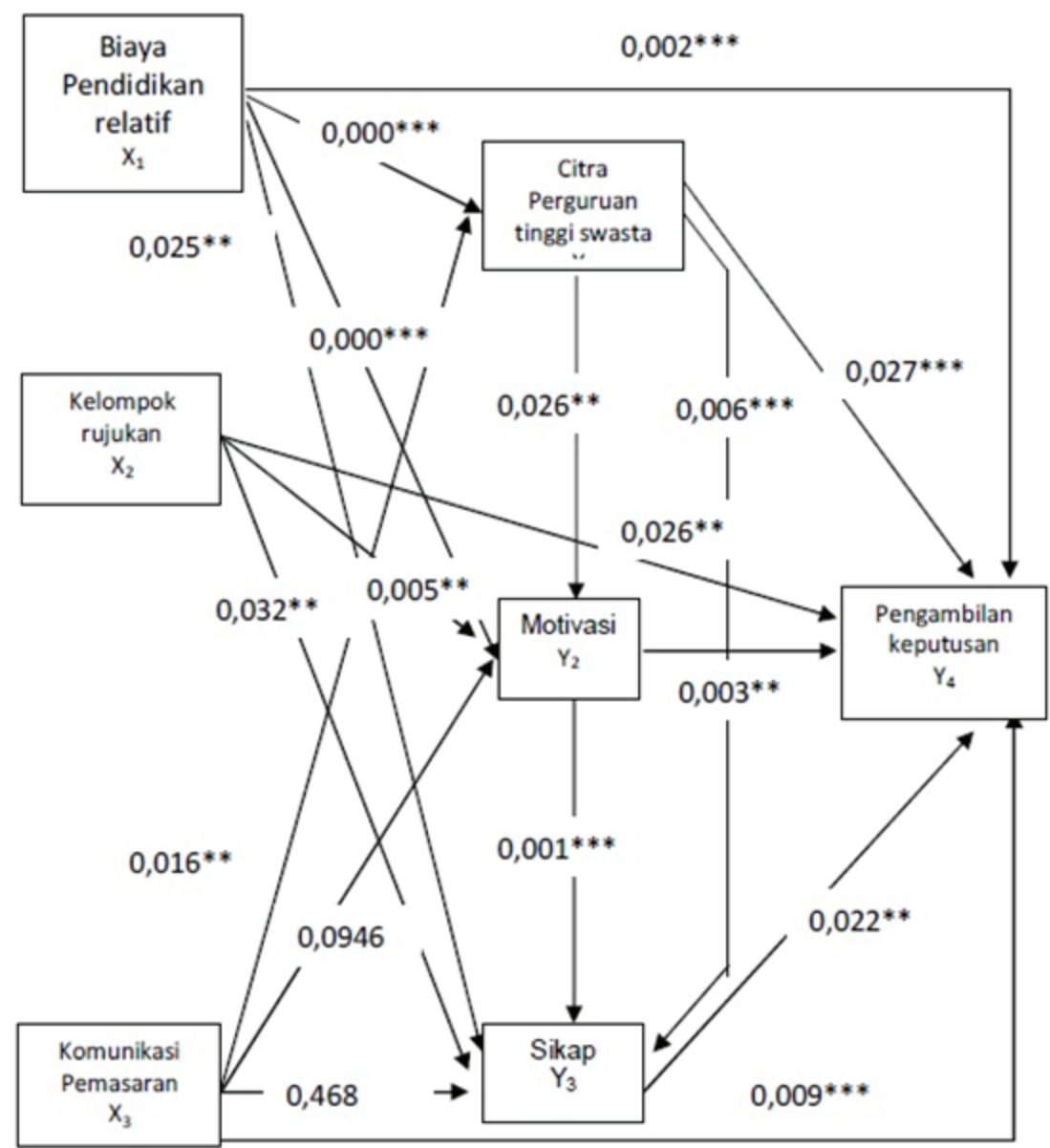

Figure 1: Structural model of decision-making to study in a private university (Jamaluddin Sawaji, Djabir Hamzah, Idrus Taba, 2011).

\section{Methodology}




\subsection{Research approach and design}

The approach used in this research is quantitative approach. The characteristics of the quantitative approach are as follows [28]:

1. Researchers using this approach test the hypothesis as its beginning.

2. The concept is in the form of a clear variable.

3. Measurements are set first before data collection and they are standardized

4. The data is in the form of numbers from the previous measurement.

5. Theories are generally causal and deductive.

6. The analysis is done using statistics, tables or graphs and

7. Explained how it relates to the hypothesis.

The research design used in this research is explanatory or confirmation research that aims to explain the causal relationship between variables through hypothesis testing and implemented by descriptive and verification approach through survey [29]. The analytical approach is a study to find facts through proper interpretation and can be useful as a problem solution. While the causal research is to study a variable or more that becomes the determinant of other variables [30].

Data collection methods used in this study is a survey which is one of the research methods commonly used for collecting quantitative data (Bovee, Arens, 1992: 188). Survey is an investigation conducted to obtain the facts of the symptoms that exist and seek factual information about the institution, social, economic, or political of a group or a region [31]. Questionnaires will be distributed to respondents by using google forms: https://docs.google.com/forms/d/e/1FAlpQLSdnQIVnd19-_9Z-

DGk1WJgsksahxfxDJnVd299KklrbPXj2bw/viewform

\subsection{Population and sample}

Population is a generalization area consisting of; Objects or subjects that have a certain quantity and characteristics set by the researcher to be studied, and then drawn a conclusion [32]. The population of this study is all active students of Vocational Education Program Universitas Indonesia which amounts 3236 students. Once calculated with Yamane formula: 


\section{Simplified formula for proportions*}

(Taro Yamane)

$$
n=\frac{N}{1+N *(e)^{2}}
$$

$\mathrm{n}$ - the sample size

$\mathrm{N}$ - the population size

e - the acceptable sampling error

Figure 2: Taro Yamane formula.

The sample is a small or controlled group that can be controlled and withdrawn from the population. The sample should be able to represent the population under study so that the results of the research conducted on the sample are considered sufficient to represent the population. Methodologically the results of a survey using samples are often more accurate [33]. It is used 0,10 the acceptable sampling error. Obtained the number of sample amounted to 97 students.

\subsection{Time and place}

Research location: Vocational Education Program Universitas Indonesia, Campus UI Depok, West Java, Indonesia, 16424

Time of study: April-May 2017.

\subsection{Data analysis techniques}

The data obtained will be processed using SPSS 1.7 software. The analysis technique used in this research are:

1. Descriptive Analysis (Univariate)

Descriptive analysis is used to describe the characteristics of respondents and research variables both exogenous variable and endogenous variable. Characteristics of respondents covering age, gender, entrance point, high school origin, parental education, and pocket money per day. While the description of variables 
include relative education costs, referral groups, marketing communications, private college image, motivation, and student decision-making.

2. Path Analysis (Multivariate)

Path analysis is the development of the regression model. This analysis test the compatibility of the correlation matrix to two or more causal models. Which is compared by researchers. The model is usually depicted in figure circle and arrow, which is the direct arrow indicates cause effect. Regression is done for each variable in the model as dependent variable to other variables so that the model indicates why. The regression weights predicted by the model then compared with the observed correlation matrix

These variables and feasibility statistics are calculated. Match of two or more models are selected by the researcher as the best model for theory development. Path model is a diagram of the image that contains about the relationship between independent variables, intermediary variables and dependent variable. A single arrow indicates a causal relationship due to exogenous or intermediary variables with dependent variables.

\begin{tabular}{|c|c|}
\hline Standardized Coefficients & Power of Correlation \\
\hline 0,0 & Very Weak \\
\hline $0,10-0,29$ & Weak \\
\hline $0,30-0,49$ & Medium \\
\hline $0,50-0,69$ & Strong \\
\hline$\geq 0,70$ & Very Stong \\
\hline
\end{tabular}

Figure 3: Analysis model.

\subsection{Analysis model}

\section{Results and Discussion}




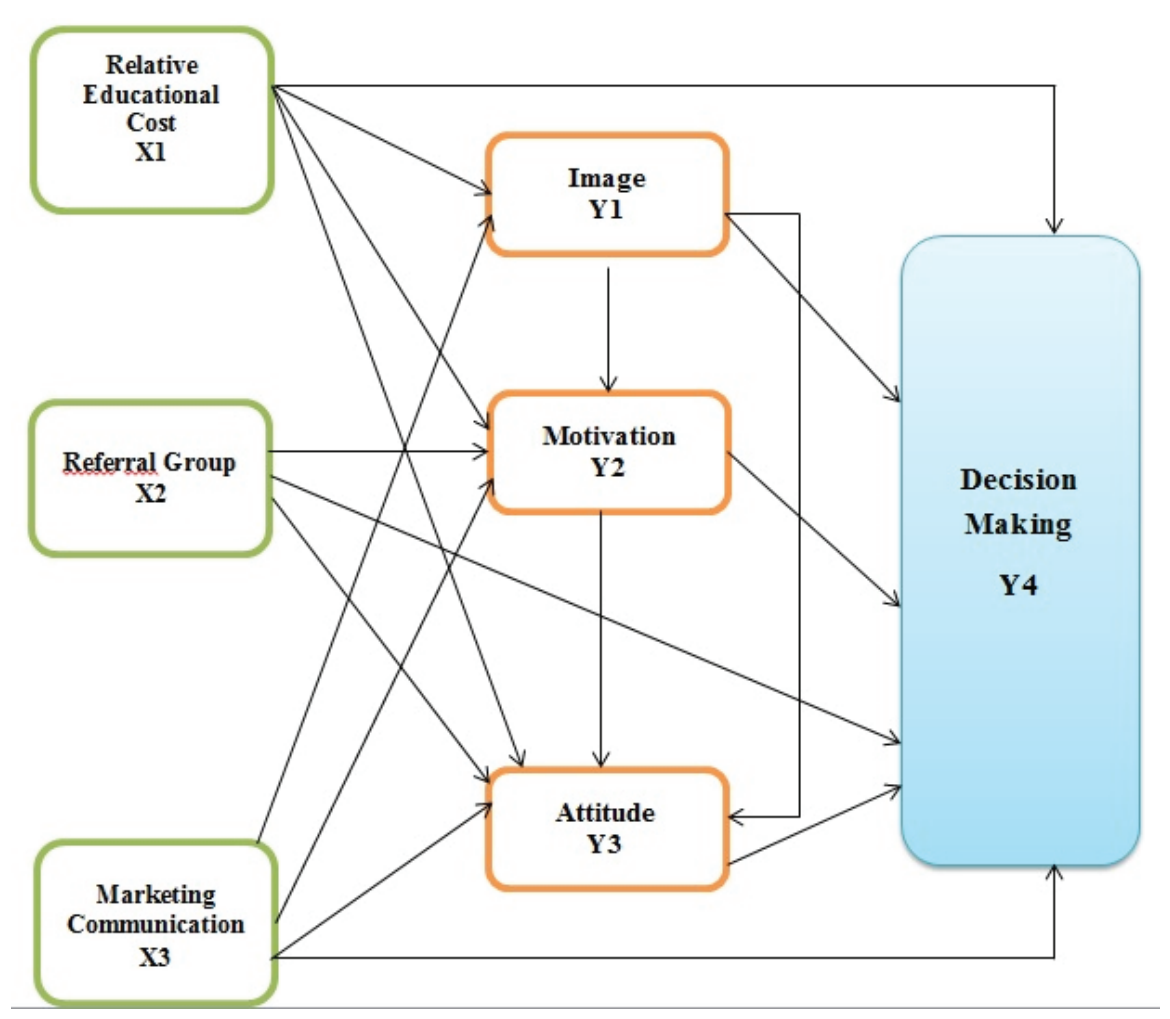

Figure 4: Analysis model.

\subsection{Reliability and validity analysis}

The reliability coefficient is the index that states the relative effect of the error score and the actual score on the respondents' answers obtained. This coefficient describes the actual variance ratio of the score on the answers obtained. This is denoted by the reliability coefficient $\alpha$. In a reliable $\alpha$ study is $>0.50$ [35].

Validity indicates the extent to which the gauge measures what will be measured. In the value of a measuring instrument, the researcher questioned whether the measuring instrument indeed reflects the variables or concepts to be measured [36]. A questionnaire is said to be valid if it is able to measure what is desired and can reveal the data of the variables studied appropriately. The high degree of instrument validity indicates the extent to which the data collected does not deviate from the description of the validity in question [37].

All the variables in this study are reliable and valid, because the alpha Cronbach and KMO and Bartlett's Test numbers are $>0.50$. So, this model can be continued to multivariate regression analysis. 
TABLE 2: Reliability and validity of the variables.

\subsection{Univariate analysis}

After doing the descriptive frequencies test to all variables, the results are:

TABLE 3: Univariate descriptive frequency of the variables.

\begin{tabular}{|c|c|c|c|c|c|c|}
\hline Variables & $\begin{array}{l}\text { Highest } \\
\text { Indicator }\end{array}$ & Mean & Mode & $\begin{array}{c}\text { Lowest } \\
\text { Indicator }\end{array}$ & Mean & Mode \\
\hline $\begin{array}{c}\text { Relative } \\
\text { Educational } \\
\text { Cost (X1) }\end{array}$ & $\begin{array}{l}\text { Easy course fee (installment course } \\
\text { fee) }\end{array}$ & 2,62 & 3 & Low course cost & 1,62 & 1 \\
\hline $\begin{array}{l}\text { Referal Group } \\
\text { (X2) }\end{array}$ & Parents & 2,02 & 1 & Grand Parents & 1,25 & 1 \\
\hline $\begin{array}{c}\text { Marketing } \\
\text { Communication } \\
(\mathbf{X} 3)\end{array}$ & School Roadshow Promotion & 2,08 & 1 & Radio Commercial & 1,25 & 1 \\
\hline Image (Y1) & $\begin{array}{l}\text { Graduates who are ready to work in } \\
\text { their respective industries }\end{array}$ & 3.13 & 3 & $\begin{array}{l}\text { Facilities, laboratories, and } \\
\text { adequate infrastructure }\end{array}$ & 2,33 & 2 \\
\hline Motivation (Y2) & $\begin{array}{l}\text { The big name of Universitas } \\
\text { Indonesia as the best university }\end{array}$ & 3,53 & 4 & Following the trend & 1,31 & 1 \\
\hline Attitude (Y3) & $\begin{array}{l}\text { I made various alternatives from the } \\
\text { information I obtained before I } \\
\text { enrolled in Vocational Education } \\
\text { Program UI }\end{array}$ & 2,94 & 3 & $\begin{array}{l}\text { I was looking for information } \\
\text { before I enrolled in } \\
\text { Vocational Education } \\
\text { Program Universitas } \\
\text { Indonesia }\end{array}$ & 2,81 & 4 \\
\hline $\begin{array}{c}\text { Decision Making } \\
\text { (Y4) }\end{array}$ & $\begin{array}{l}\text { I communicate, get along, and have } \\
\text { good relationship with lecturers }\end{array}$ & 3,61 & 4 & $\begin{array}{l}\text { I communicate, get along, and } \\
\text { have good relationship with } \\
\text { cleaning service and security }\end{array}$ & 2,48 & 2 \\
\hline
\end{tabular}

The greatest good judgment of all variables in this study is the variables Image ( $\left.Y_{1}\right)$, Motivation ( $\left.\mathrm{Y}_{2}\right)$, Decision-making ( $\left.\mathrm{Y}_{4}\right)$. Specifically, in the Image ( $\left.\mathrm{Y}_{1}\right)$ variable, the best image available to the respondents is a graduate of vocational higher education ready to work in related industries. Then, if you look from the Motivation ( $\left.Y_{2}\right)$ variable, it turns out that the biggest motivation of respondents to study in vocational college is because the big name of the Universitas Indonesia as the best university. Regarding the variable Decision-making $\left(\mathrm{Y}_{4}\right)$, it is proved that this variable has the highest mean values among other variables, the respondents have good relationship and communication with the lecturers in Vocational Education Program Universitas Indonesia. 
It should be noted that external factors have low mean values. Relative Educational Cost $\left(X_{1}\right)$, Referral Group ( $\left.X_{2}\right)$, Marketing Communication $\left(X_{3}\right)$ were not paid much attention by respondents. It is interesting to see that the tuition that can be paid becomes the majority of respondents' answers regarding Relative Educational Cost ( $\left.X_{1}\right)$ variable. Then, on the Referral Group (X2) variable, the parent is still the person who is listened by the respondents in choosing the college. For the domain of Marketing Communication $\left(X_{3}\right)$ variables, roadshow to schools are the one most chosen and noticed by the respondents.

\subsection{Multivariate analysis}

After performing multiple regression analysis of path analysis based on the analysis model, Beta $(ß)$ is obtained for each correlation in the model and its significance number. According to Heise (1969) the purpose of path analysis is to obtain a significant model by eliminating the relationships between variables that are not significant. The insignificant relationship is having a level of significance above 0.050 . Thus the relationship between these variables must be omitted or removed from the model.

Figure 5: Analysis model with beta and significance number.

Of all the variables (endogenous and exogenous), it appears that the relation has significance is the correlation between:

1. $X_{1} \rightarrow Y_{1}$

2. $\mathrm{X}_{2} \rightarrow \mathrm{Y}_{2}$

3. $Y_{1} \rightarrow Y_{2}$

4. $Y_{1} \rightarrow Y_{3}$

From the aforementioned correlation, it can be concluded that the largest Beta ( $(B)$ is the relationship between the 'Image $\left(\mathrm{Y}_{1}\right)^{\prime}$ 'variable to 'Motivation $\left(\mathrm{Y}_{2}\right)^{\prime}$ '. This proves, 
that the image of an institution, strong influence on the motivation of respondents to choose college in Vocational Education Program UI. While there is a correlation that has a relationship but does not contribute, namely on the relationship between variables 'Referral Group' to 'Motivation' with the number Beta - 0.371. This proves that the students listen to the opinions of the Referral Group, but that does not ultimately motivate them to choose college in Vocational Education Program UI.

Here is an analysis model that can be applied to see the factors that ultimately influence the decision of the respondents to choose to enroll in the Vocational Education Program Universitas Indonesia

Figure 6: Final Analysis Model with Beta and Significance Number.

\subsection{Conclussion and recommendations}

On the external factor, the Easy Course fee is a good financial strategy, because most of the respondents are chosen by the respondents as the basis for their studying in UB Vocational Education Program. Then Parents, it turns out is the most referral group hearing opinion by prospective students. In connection with marketing communication, School Roadshow Promotion is the most popular by students, because in roadshow promotion audience will receive explanation of product/service with more clear and comprehensive.

On internal factors, it is surprising that the image that has been embedded in the students is 'Graduates who are ready to work in their respective industries'. This means they understand well, that graduates of vocational higher education are graduates who are ready to work. In terms of motivation, The big name of the Universitas Indonesia as the best university is their greatest motivation to decide to enroll in Vocational Education Program UI. Their behavior was also very objective by stating they made various alternatives from the information I obtained before I enrolled in the Vocational Education Program UI. 
It should be underlined that students who have enrolled in Vocational Education Program UI feel they have communicate, get along, and have good relationship with lecturers. This indicates that the lecturers in the Vocational Education Program UI are quite familiar with the students, because the power distance culture is not so lifted in their daily life.

Regarding student decision-making to study in Vocational Education Program of Universitas Indonesia, the correlation and significance is only influenced by external factors 'Relative Educational Cost' and 'Referral Group', then internal factors like 'Image', 'Attitude', and 'Motivation'. It should be underlined, it turns out internal factors that have greater power and significant to influence the choice of respondents. Especially, 'Image' that affects 'Motivation' and 'Attitude'.

Suggestions that can be given to vocational higher education activists are:

1. Because the image of educational institutions is apparently the most important thing that affects the choice of prospective students in choosing a college. So for vocational education institutions, a good Image must be built. For Vocational Program Universitas Indonesia, it is helped by big name of Universitas Indonesia, but it would be nice, Vocational Education Program Ul begin to improve and maintain the desired image. It has been found that the Vocational Higher Education Program of Ul can be raised, that students and prospective students have enough understanding, higher education vocational will produce graduates who are ready to work to enter the industrial world.

2. For the field of Marketing Communication and Marketing Public Relations Higher Education Program Vocational UI must improve the program 'School Roadshow Promotion', because it proved to be the most effective to provide more understanding to prospective students. In roadshow activities, the image that will be built earlier can also be delivered well by public relations and marketing practitioners to the audience.

3. Vocational colleges throughout Indonesia, should understand, that higher education requires more attention vocation in terms of image formation in the community. These negative stigma should be removed from the minds of the people, through a comprehensive understanding of what is actually meant by vocational education. This requires the support of many parties as bearers and agents of change, ranging from students, educational staff, lecturers and leaders to at all times spread positive image of vocational education to audiences through various communication channels. 


\section{Acknowledgment}

This research was supported by Vocational Education Program Universitas Indonesia. The author would like to thank all the lecturer colleagues from Communications Studies of Vocational Education Program of Universitas Indonesia who provided insight and expertise that greatly assisted the research, although they may not agree with all of the interpretations/conclusions of this article. The author would also like to show his gratitude to Professor Sigit Pranowo Hadiwardoyo, DEA and Dr. Padang Wicaksono for sharing their pearls of wisdom and knowledge during the course of this research. The author is thankful to 'anonymous' reviewers for their insights and immensely grateful to her students Rasyiqa Tharifa, A.Md., Fasya Maydya Ainani, and Nur Meividiani for their support on spreading questionnaires. Any errors and imperfections in this research are author's own and should not tarnish the reputations of the esteemed persons mentioned.

\section{References}

[1] Vocational Education: A Historical Perspective Author(s): William R. Ogden Source: The High School Journal, Vol. 73, No. 4 (Apr. - May, 1990), pp. 245-251 Published by: University of North Carolina Press Stable URL: http://www.jstor.org/stable/ 40364875 Accessed: 04-05-2017 09:24 UTC

[2] ASTE. "Career and Technical Education - ASTE - aste.usu.edu". aste.usu.edu. Retrieved 2016-02-27.

[3] http://www.netralnews.com/news/pendidikan/read/31764/pemerintahan. jokowi.jk.dan.revitalisasi.pendidikan.vokasi

[4] http://www.republika.co.id/berita/pendidikan/eduaction/15/05/20/nom8malulusan-vokasi-lebih-siap-hadapi-mea-daripada-sarjana

[5] The Global Competitiveness Report 2016-2017 is published by the World Economic Forum within the framework of the Global Competitiveness and Risks Team. Professor Klaus Schwab, et al. World Economic Forum Geneva Copyright (c) 2016 by the World Economic Forum

[6] The Global Competitiveness Report 2015-2016 is published by the World Economic Forum within the framework of the Global Competitiveness and Risks Team. Professor Klaus Schwab, et al. World Economic Forum Geneva Copyright (c) 2015 by the World Economic Forum 
[7] An Analysis of Student's Decision Making to Choose Private Universities in South Sulawesi. Jamaluddin Sawaji, Djabir Hamzah, dan Idrus Taba. E-Journal Pascasarjana Universitas Hassanudin, 2011.

[8] What kind of (vocational) education is required for economic development? Reflections on vocational training's contribution to private sector development. Margarita Langthaler. Ös

[9] https://www.theguardian.com/global-development-professionals-network/ 2014/jan/15/youth-unemployment-vocational-training-finlandterreichische En

[10] http://vokasi.ui.ac.id/rз/profil/sejarah/

[11] http://simak.ui.ac.id/program-yang-ditawarkan-vokasi.htmltwicklungspolitik2

[12] http://www.antarajatim.com/lihat/berita/196921/revitalisasi-pendidikan-tinggivokasi-tanpa-diskriminasi

[13] Hawkins, Del I., Roger J., Best dan kanneth A., Coney, 1998. Consumer Behavior, USA:Irwin McGraw-Hill.

[14] Kotler, Philip, et al., 2004. Marketing, 6th ed, Pearson Edition Australia: Frenchs Forest, NSW.

[15] Hossler, D., \& Gallagher, K. (1987). Studying student college choice: A three-phase model and the implications for policymakers. College and University, 62(3), 207-221.

[16] Shiffman, Leon G and Kanuk, Leslie, Laser, 2007, Perilaku Konsumen, Edisi ketujuh, Indeks, Jakarta.

[17] Mowen, J. C., Minor M., (1998), Consumer Behavior. 5th edition, Prentice Hall, New Jersey.

[18] Dewa, Ndaru Kusuma. (2009). "Analisis Pengaruh Kualitas Produk, Daya Tarik, Promosi dan Harga Terhadap Minat Beli (Studi Kasus Star One di Area Jakarta Pusat)". Semarang. Fakultas Ekonomi Universitas Diponegoro.

[19] Solomon, M. R., (2002), Consumer Behavior: buying, having, and being. Prentice Hall International, Upper Saddle River, New Jersey. Stanton, William J, et al. 1991,

[20] Michel Laroche, Roy Toffoli, Chankon Kim, and Thomas E. Muller (1996),"The Influence of Culture on Pro-Environmental Knowledge, Attitudes, and Behavior: a Canadian Perspective", in NA - Advances in Consumer Research Volume 23, eds. Kim P. Corfman and John G. Lynch Jr., Provo, UT: Association for Consumer Research.

[21] Paul, Peter. J dan Jerry C. Olson, 2000, Consumer Behaviour: Perilaku Konsumen dan Strategi Pemasaran, jilid 1 dan jilid 2, Jakarta: Erlangga.

[22] Assael, Henry (1998), Consumer Behavior and Marketing Action, 6th ed, New York: South Western College Publishing. 
[23] Supranto, J., (2007), Perilaku Konsumen dan Strategi Pemasaran: Untuk memenangkan persaingan bisnis, Mitra. Wacana Media, Jakarta

[24] Engel, James F, Blackwell, Rogre D and Miniard, Paul W, (1994), Perilaku Konsumen, Jilid-1, Binaputra Aksara, Jakarta

[25] J. Setiadi, Nugroho, SE., MM., 2003, "Perilaku Konsumen Konsep dan Implikasi untuk Strategi dan Penelitian Pemasaran". Jakarta: Kencana.

[26] Tony Meenaghan, David Shipley, (1999) "Media effect in commercial sponsorship", European Journal of Marketing, Vol. 33 Issue: 3/4

[27] Prasetijo, Ristiyanti dan Ihalauw, John J.O.I, 2005, Perilaku Konsumen, Andi Offset, Yogyakarta

[28] Neuman, W. Lawrence. 2003. Social Research Methods: Qualitative and Quantitative Approaches, Ed.5. USA: Pearson Education Inc

[29] Rahayu, Sri, 2005, SPSS Versi 12,0 Dalam Riset Pemasaran, Alfabeta: Bandung.

[30] Nazir, Moh, (2005), Metode Penelitian, Ghalia Indonesia, Bogor

[31] Singarimbun, Masri dan Sofian Efendi. Metode Penelitian Survei. LP3ES. Jakarta. 1989.

[32] Ruslan, Rosady. 2004. Metode Penelitian:Public Relations dan Komunikasi.

[33] Eriyanto. 1999, Metodologi Polling Memberdayakan Suara Rakyat, PT. Remaja.

[34] http://www.statisticshowto.com/factor-analysis/

[35] Guildford, J.P. 1978. Fundamentals Statistic in Psychology and Education. New York: Mc. Graw-Hill.

[36] Singarimbun, Masri dan Sofian Efendi. Metode Penelitian Survei. LP3ES. Jakarta. 1989.

[37] Arikunto, Suharsimi. 1996. Prosedur Penelition. Jakarta: Penerbit Rineka Cipta 